\title{
Citizenship Politics \\ (Reviewing the Meaning of Democracy in Majanggut I Village, Royal District Pakpak Barat Regency)
}

\author{
Budi Ali Mukmin ${ }^{1}$, Prayetno ${ }^{2}$, Bakhrul Khair Amal ${ }^{3}$, Nurhairani ${ }^{4}$ \\ ${ }^{1}$ Program of Study in Pancasila and Citizenship Education, Universitas Negeri Medan, Indonesia \\ ${ }^{2}$ Program of Study in Pancasila and Citizenship Education, Universitas Negeri Medan, Indonesia \\ ${ }^{3}$ Program of Study in Anthropology, Universitas Negeri Medan, Indonesia \\ ${ }^{4}$ Program of Study in Primary School Teacher Education, Universitas Negeri Medan, Indonesia \\ bamsarumpaet@gmail.com
}

\begin{abstract}
Citizenship Politics in Majanggut I Village is the topic that will be discussed in this research. Maintaining the consolidation of democracy in the midst of the high level of cultural, religious and ethnic diversity is not an easy matter to implement. A political integration formula is needed to combine the demands of unity and diversity. The liberal democracy that is developing at the moment is apparently understood differently by the people in North Sumatra because it is given through a state-centric mechanism. This study uses descriptive qualitative methods. The use of fieldwork with the observation method was carried out. In addition to observation, interviews were also carried out both to the Village Government, Majanggut I, and to the village community. In addition to interviews, various kinds of documentation and literature studies were also used to strengthen the results of this study. The results showed that Majanggut I villagers' understanding of democracy is still limited to the conception of political contestation. Opportunities for locality values to be accommodated in democracy are very open, even though the values of locality in the village are fading away. The Citizenship Politics in Majanggut I Village has not placed citizens as actors of democracy itself. The people of Majanggut I village are still the objects of democracy itself. This indication can be seen from the lack of participation of the village community in the development process in the village and in the process of political development, including in the contestation of village head elections.
\end{abstract}

Keyword: Citizenship politics; democratic consolidation; political contestation; village head election

\section{Introduction}

Citizenship Politics in Majanggut I Village is the topic that will be discussed in this research. Maintaining the consolidation of democracy in the midst of the high level cultural, religious and ethnic diversity in North Sumatra is not an easy matter to implement. A political integration formula is needed to combine the demands of unity and diversity. The liberal democracy that developed at this time was apparently understood differently by the people in North Sumatra because it was given through a state-centric mechanism. Indications of different meanings of democracy can be seen from the case of village head elections held simultaneously in North Sumatra in 2018. Election of Majanggut I village heads in the Kerajaan District, Pakpak Barat Regency ended in chaos which resulted in dozens of injured victims. This conflict has an impact on the power vacuum in Majanggut I because Pakpak Barat Regency was reluctant to appoint the elected village head on 25 February 2019.

The above argument becomes more apparent when Verdy Hadiz (2003) conducted a research with quite astonishing results that reform has never been completed in North Sumatra. Hadiz said that after the New Order fell, what actually happened in North Sumatra 
was that efforts to fight for power in the local political constellation were greater and tended to violate the democratic norms.

The political significance of citizenship to interpret democracy in North Sumatra especially in Majanggut I village is interesting to study because we need a new perspective to see the practice of Indonesian democracy. Specifically, this study wants to review the consolidation of democracy in North Sumatra based on aspects of locality that can be used as an alternative model to improve the liberal democratic system that is often misinterpreted in each region. The case of the conflict that occurred in the election of Majanggut I village chief in the Royal District of Pakpak Barat Regency became the initial foothold in this research that aimed to peek at opportunities to build democracy in a different way by adopting longstanding locality values.

Re-setting the democratization agenda by considering aspects of locality is offered by Santoso (2018) to see the possibility of involving citizens as an entry point for viewing the case in North Sumatra. With a simpler language, Santoso's ideas to be translated into democratic development are no longer imposed by the state, because each locality in Indonesia has actors with a certain style where they carry out their respective roles by establishing certain patterns of relations that uphold high values that they believe so that they involve themselves in collective action to overcome problems together (Santoso, 2018). The politics of citizenship can be said as a locomotive to fill the spaces of locality that have diversity in North Sumatra. A bottom-up design of democracy will be born if the involvement of citizens has the right to determine their identity in democracy.

\section{Review of Literature}

Top-Down design of democracy will ignore the values of the locality that exist in each region and tend to place citizens as objects of democratic development. North Sumatra, which has a diversity of ethnicities, ethnicities, languages, religions, will experience complicated things if the meaning of democracy is limited to the spaces of political contestation alone. Therefore, the definition of democracy can be interpreted in different ways by each citizen who has a diverse identity. In short, to define democracy, the most frequently occurring thing is euphoria to express the politics of ethnic identity, politics of religious identity, and ethnicity as the frontline as vote-getters.

Borrowing the arguments built by Berenchot and Klinken (2019), democracy works well in Indonesia if it is the citizens who make it work, not because the political elites are building the right democratic institutions. But the opposite can also happen, if democracy deteriorates, it is also because citizens have not done enough to protest the selfishness of the political elite that puts diversity in identity into a capital in every political contestation. Citizens have the fundamental goal to move the life of democracy following the state of the social-political environment. The involvement of citizens as the subject of democracy will give birth to a strong citizen character. Citizenship politics is not merely a series to fight for a sense of injustice committed by various groups of citizens (Hiariej and Stokke; 2018). Citizenship politics urges citizens to create a political order that provides spaces for all differences in the regions which has a multi-nationality. The democratic system is considered a mechanism that can accommodate a person's civil and political rights. As proposed by Kymlica and Gutman (1993), the biggest challenge of democracy amid high diversity lies in 
how to accommodate national and ethnic differences in a stable and morally defensible manner (Kymlica; 2015).

Theoretically, the design of citizenship political research in North Sumatra contributes to efforts to maintain the consolidation of democracy by promoting the values of the locality. The incorporation of democracy has the same breath as multicultural politics. Multicultural politics provides space for each individual to freely express the cultural values of each different identity to obtain their rights. On the other hand, the consolidation of democracy exists to accommodate cultural values. Culture is then managed to become a rule of the game together, and the consolidation of democracy is successful when cultural values owned by the community can strengthen people's organizations that can accommodate all their interests. The hope is that people's organizations synergize with the state, so that the synergy results in a power structure based on agreement, constitutional rights that can be accepted collectively, the state acts fairly and impartially (Parekh; 2008).

Theoretically, this research is useful for the development of a democratic model in Indonesia, especially in North Sumatra, by prioritizing the values of locality held by each region. This research plan will provide instructions to be followed up on how to develop locality values to be integrated into the democratic system by prioritizing citizens as actors to care for democracy. However, that has not been the norm. Citizens' participation to become demos is precisely due to many reasons; it could be due to the arrogance of the conflicting identity politics, religious identity politics, even political participation arises through votebuying.

In other words, the process of democratization in Indonesia, especially in Sumatra, needs to be reviewed. Once again, the democratization process in North Sumatra must require local values. Like it or not, the process of democratization that has developed in Indonesia has led to liberal democracy, which logically has a substantial impact on the values of locality in North Sumatra. Local cultural values that exist in North Sumatra are no longer able to be a bond of togetherness to eat democracy. Citizens are actually trapped in the euphoria of democracy, which is apparently understood differently by people who have a diversity of cultures, ethnicities, religions because democracy that is developing at this time can be said to be given through a state-centric mechanism.

Theoretically, this research is useful to bring up variants of the theory of efforts to consolidate democracy by using a democratic model by prioritizing the values of locality, especially those in North Sumatra. A new perspective is needed to see democracy in North Sumatra without destroying the democratic order that has been implemented with a localitybased democracy approach. Local based democracy exists to provide an excellent opportunity for every citizen who has different identities to show their existence in the life of the state.

\section{Research Method}

The research method and design that will be used in research is a qualitative research method. Bogdan and Taylor argue that qualitative methodology is a study that will produce descriptive data in the form of written or oral words from people and observed behavior. To explain how the Politics of Citizenship in North Sumatra, this study also uses fieldwork, which includes the work of recording, observing, listening, feeling, collecting, and capturing all phenomena, data, and information about the case under study. To get comprehensive data, this research will use several data search techniques. 


\subsection{Literature Study}

The first step that will be taken is the study of literature in book form, the results of research relevant to the theme raised. This is done to increase the theoretical and conceptual understanding of the object under study. In addition to literature, the reading of research objects will also be carried out through media studies. With this media study, researchers are expected to obtain more information about the object under investigation, especially regarding events that have occurred.

\subsection{Interview}

The interview is a method of data collection that is done by giving questions to resource persons who are considered to be the focus of research or parties who provide information. In other words, an interview is a form of meeting between researchers and respondents where the answers from the interview will be used as raw material (Horizon, 2007). On the other hand, Steward (2007 in Horizon) said that interviews are an excellent tool to bring to life a research topic where interviews can provide data on contemporary subjects that have not been extensively studied.

\subsection{Observation}

Observation is a method that is closely related to conducting interviews. Observation is a process of observation of the phenomena that are felt to be essential to be used as information in research. This study uses observations that tend to focus on situations and conditions.

Data processing in this study was divided into several sections. First, analyzing data generated from fieldwork. Second is data reduction. The third is preparation to become one unit. Fourth, to categorize, the Fifth check the validity of the data, which is an attempt to determine which entries meet the research requirements or not. If there is some data that does not meet the criteria, it will be refined. The sixth is the analysis of data based on the theory or frame of mind used.

Data obtained from interviews from one informant will be cross-analyzed with other informants, so it will be known whether there are differences of opinion or information from each source. If there are differences, the reasons will be known without reducing the objectivity of the study. Furthermore, researchers will analyze the data obtained, and the data will be examined again by cross-checking analysis with literature sources, so understanding and depth of analysis can be obtained.

\section{Discussion}

\subsection{The Contest of Majanggut Village Head Election I}

Majanggut I Village is an area of Royal District of Pakpak Barat Regency. Majanggut I village itself consists of four hamlets, namely NatamJehe, NatamJulu Hamlet, Kuta Hamlet, and Kuta Batu Hamlet. The area of the royal village is $15.40 \mathrm{Km}^{2}$ with a population of 938 people. If seen in terms of ethnic identity, the majority of Majanggut I villagers are from the Simsim tribe. In terms of religion, the majority of Majanggut I villagers embraced Christianity, and some embraced Islam. Agriculture is the main livelihood of the people of Majanggut I village. 
During the Jokowi-Jusuf Kalla government era, village administration had a strategic role for national development. The commitment of the Jokowi-JK government (Jokowi Widodo-Jusuf Kalla) to develop villages has been set out in NAWACITA specifically in part 3 namely "Building Indonesia from the periphery by strengthening regions and villages within the framework of the Unitary State of the Republic of Indonesia" as an entry point for each village in Indonesia quickly change and immediately clean up to alleviate poverty in the village, improve welfare in the village, and accelerate economic development in the village. One of the efforts made by the government to implement the NAWACITA program is by giving birth to Law No. 6 of 2014 concerning Villages and the issuance of Government Regulation No. 60 of 2014 concerning Village Funds sourced from the state budget.

Behind the tumult of the country's attention to the villages, the transition to democracy in rural areas began to experience a shift. While the village head election was previously not very attractive to the village community, nowadays, the village head election began to give birth to new political elites in the rural areas. With direct elections, the participation of village communities began to emerge calculative rational involvement (calculation) because it was driven by the gift of the number of village funds that had been rolling at this time. Political awareness of the Majanggut I village community began to rise in deciding political matters in the countryside even though the awareness of the village community to politics was not completely separated from the patron-client, ethnic identity politics, or religious identity politics.

The peace of the Majanggut I noble village was disturbed when the village head elections were held simultaneously on October 24, 2018. The election of the village head of Majanggut I was attended by four pairs of candidates for village heads, namely Merson Jobel Solin, Marie Solin, Tony Berutu, and Cipto Aceh. The trigger for the chaos in the Majanggut I village head election began with the registration process for the village head election, where one partner, Tony Berutu, included the identity of the village head on the registration form. This made the P2KD committee (Village Head Election Committee) immediately annul the registration file of one of the candidates for the village head candidate pair. Tony Berutu, as the disallowed candidate pair, was dissatisfied when their political rights were ignored because the P2KD did not provide time to fix the registration form file.

For the head of the P2KD Majanggut I village, Hasmer Sitanggang, the reason for the alienation of one of the pairs of candidates for the village head was the wrong registration form file and the lack of time to correct the registration form. The following is an excerpt from the interview with the head of the P2KD Majanggut I village recorded on October 24, 2019.

"There was an administrative error in registering one candidate for the village head. He (Tony Berutu) should have listed the village head candidate instead of the village head. We do not have time to correct the form in accordance with the technical guidelines from the local government."

The village head election committee remained adamant that one of the candidate pairs could not take part in the village head election and the village head election was carried out according to a predetermined schedule and resulted that Merson Jobel Solin was the winner in the village head election with a recapitulation of $76 \%$ of votes.

The problem of the Majanggut I village head did not stop. After Merson Jobel Solin was elected village head, it turned out he had not been inaugurated for six months. One of the clauses for delaying the inauguration of the elected village head was due to a lawsuit 
addressed to P2KD to the Medan PTUN on September 9, 2018, by Tony Berutu and Cipto Aceh. The Pakpak Regency government assumes that it is still waiting for the Medan PTUN decision because PTUN granted the lawsuit Tony Berutu and Cipto Aceh to revoke the P2KD decision in holding the village head election.

On the other hand, the elected head has the argument that the elected village head must be appointed because the lawsuit does not correlate with the results of the village head election, because the one being sued is the P2KD in selecting the village head candidates and not the results of the village head election. It was on this basis that the villagers came to the Pakpak Regent's office to hold a demonstration, and this was where the incident occurred, where the villagers argued and had physical contact with the security forces.

After waiting for the results of the Medan PTUN, which made an 'inkrah' (fixed decision) and the absence of a 14-day appeal by the plaintiff, on 29 August 2019, elected village head Merson Solin was appointed by PJ Pakpak Barat Regency. What is interesting about this finding is not how the village head election process is concerned, but far from that, the problems in Majanggut I village left some critical questions. First, understanding how villagers understand democratic practices. Second, is the understanding of the village community about the institutions of democracy still considerably low.

\subsection{Reviewing the Meaning of Democracy in the Rural Areas}

In the village head election, the democratization process can be realized naturally according to the needs that develop in the village. However, do not be too big if juxtaposed with national elections, the political behavior of rural communities will become the main commodity by national political elites who are able to manipulate political power from outside the village with the result that what actually happens is not democratization but refeudalization in the sense coercive people must be ordered to follow the instructions of superiors or elites (Kartodirdjo, 1990).

This is where we have to re-examine the practice of democracy in the countryside because politics in the country does not necessarily correlate directly with the dynamics of national politics. Therefore, redefining the practice of democracy in rural areas needs to be further considered. In other words, the current process of democratic liberalization does not need to be forced to develop in the countryside. Of course, the argument is not without reason, because each village can certainly have local values that have the potential to be used as a democratic rule for the village itself. One way to awaken the values of locality in the practice of democracy in rural areas is to hone the politics of the citizenship of the village community by putting the village community as the subject of the practice of democracy itself. The following is a model of citizenship politics that will be offered in the practice of democracy in the countryside.

Table 1. Political Model of Citizenship Based on Locality Values

\begin{tabular}{|l|l|l|}
\hline \multicolumn{1}{|c|}{ Level } & \multicolumn{1}{|c|}{ Locality Norms and Value } & \multicolumn{1}{c|}{ Behavior } \\
\hline Local Elites & $\begin{array}{l}\text { Significant leaders of } \\
\text { community organizations, } \\
\text { customary leaders, believe in } \\
\text { the legitimacy of democracy } \\
\text { that adopts local values, believe }\end{array}$ & $\begin{array}{l}\text { Local elites, indigenous groups } \\
\text { respect each other's right to } \\
\text { compete for power peacefully, } \\
\text { distance themselves from } \\
\text { violence and comply with }\end{array}$ \\
\hline
\end{tabular}




\begin{tabular}{|l|l|l|}
\hline & $\begin{array}{l}\text { that the democracy to be formed } \\
\text { is a democracy that has the } \\
\text { support of getting support from } \\
\text { all components of society }\end{array}$ & $\begin{array}{l}\text { laws, constitutions and norms } \\
\text { that apply in society and are } \\
\text { accepted together. Local elites } \\
\text { should avoid rhetoric that can } \\
\text { incite their followers to } \\
\text { violence. }\end{array}$ \\
\hline $\begin{array}{l}\text { Community / customary } \\
\text { organizations. }\end{array}$ & $\begin{array}{l}\text { Organizations that are built } \\
\text { consciously by mutual } \\
\text { agreement, based on shared } \\
\text { interests and politically } \\
\text { significant social movements, } \\
\text { support the legitimacy of } \\
\text { democracy. }\end{array}$ & $\begin{array}{l}\text { There are no popular } \\
\text { organizations, adat institutions } \\
\text { will overthrow democracy or } \\
\text { use fraudulent violence or } \\
\text { unconstitutional or anti- } \\
\text { democratic methods }\end{array}$ \\
\hline $\begin{array}{l}\text { Local citizenship with } \\
\text { cultural values of culture } \\
\text { in North Sumatra. }\end{array}$ & $\begin{array}{l}\text { Citizenship is the main } \\
\text { locomotive in democracy. There } \\
\text { is a mutual agreement that the } \\
\text { values of local wisdom become } \\
\text { a reference for democracy and } \\
\text { do not conflict with the policies } \\
\text { set by the government that is } \\
\text { legitimate. }\end{array}$ & $\begin{array}{l}\text { No anti-democratic movement } \\
\text { has been established based on } \\
\text { mutual agreement. }\end{array}$ \\
$\begin{array}{l}\text { The state has a role to } \\
\text { implement policies that are just } \\
\text { and support all groups. }\end{array}$ & $\begin{array}{l}\text { The state must guarantee } \\
\text { political goods and public } \\
\text { goods to facilitate what the } \\
\text { community needs. }\end{array}$ \\
\hline Nation/state & aption model of
\end{tabular}

Source: This model was adopted and developed from the democratic consolidation model of Larry Diamond's book. 2003. Developing Democracy toward Consolidation. Yogyakarta. IRE

Theoretically, this research would like to come up with a variant of the theory of efforts to consolidate democracy by using a democratic model by prioritizing the values of locality, especially in the village of Majanggut I. locality based. Local based democracy exists to provide an excellent opportunity for every citizen who has different identities to show their existence in the life of the state.

The case for the election of village heads in Majanggut I village illustrates that it is deemed necessary to review the meaning of democracy in every region of Indonesia, which has its characteristics. Majanggut I village has the opportunity to involve local values in democratic practices. However, the biggest obstacle that must be faced by rural communities is an understanding of how the nature of the democratic practice itself can be integrated with existing locality values.

Majanggut I community's understanding of how democracy is practiced is still far from what we imagine. As one respondent said, people only understand democracy is only limited to elections. The following are excerpts of interviews with informants on behalf of the Allied Kammit on October 24, 2019.

"We only understand that democracy is a village head election, the election of a Regent, Governor, President, and Legislature. That's all, if we don't know about others ..." 
The interview passage above illustrates that the people of Majanggut I village are still categorized as passive and tend to be objects of democracy. The factor of education, the economy can be a trigger why they have limitations in that regard. Still, the state (district government) should be quick to anticipate how democratic practices should put village people as the main actors in the practice of democracy in the village.

In the political aspect of citizenship, the chaos in the election of Majanggut I village heads in two dimensions. First, the occurrence of mal procedure carried out by the P2KD committee in the selection of candidates for village heads. If referring to Pakpak Barat Regency Regulation Number 8 of 2008 concerning Procedures for Nominating, Election, Inauguration, and Dismissal of Village Heads in Chapter II section 3 of article 8, states that the task of the P2KD is to examine the identity of prospective candidates based on the specified requirements. In this section, the P2KD committee should review the criteria file of the potential village head carefully. If it is found that one of the village head candidates did not meet all the requirements. This is where the P2KD review and then return the village head candidate's requirements file. However, the P2KD at that time argued that the regent's regulation did not explain the provision, even though Article 9 of the Pakpak Barat Regent's regulation also indicated that the $\mathrm{P} 2 \mathrm{KD}$ had the authority to resolve problems arising in the election of village heads.

The suspicion arising from this incident is the occurrence of an affair between a village head candidate and a P2KD member. In the practice of citizenship politics, this is a taboo thing to do. The people of Majanggut I village who have strong kinship values struggle to resolve administrative issues that the community itself should be able to.

Second is the fading of locality values in Pakpak Bharat. Nitalu Sukut (are locality values owned by Majanggut I villagers) owned by Majanggut I villagers. Nitalu Sukut are values that contain together where various kinds of problems, starting from family problems to village government issues, can be resolved together. SukutNitalu will give birth to a Pertaki (adat head) who is elected along with the people of the village of Majanggut I. It is this Pertaki that has a significant role if various issues arise in the government system. However, at present Pertaki does not have a vital enough role as a mediator to solve problems that arise. Ideally, the values of locality in SukutNitalu can be adopted in democratic practices when rural communities are deadlocked to resolve bitter conflicts when political contestation is held in the village.

One of the waning values of SukutNitalu is that Pertaki is also involved in practical political activities at the village level, which causes the villagers' legitimacy towards Pertaki to be increasingly low. As argued by Santoso and Nuruddin Al Akbar (2018), ideally, citizens are active citizens or so-called (demos), who are sensitive or are always called to involve themselves in public affairs. However, that has not been the trend. The participation of villagers to become demos is precisely due to many reasons, it could be because of the arrogance of the politics of identity that flies, the politics of religious identity, and even political participation arises through vote-buying.

\section{Conclusion}

We do not need to insist that the democratic system must be practiced the same in all regions in Indonesia, including in rural areas. Indeed, villages must be able to demonstrate the existence of locality values to collaborate with the democratic system itself. One of the 
keywords to realize this is to put citizens (villagers) as the main locomotive in the democratic system itself so that it will give birth to a consolidation of democracy based on locality values.

Locality cultural values that exist in Majanggut I Village are no longer able to become a binder of togetherness to eat democracy. Citizens are trapped in the euphoria of democracy, which seems to be understood differently by people who have a diversity of cultures, ethnicities, religions because democracy that is developing at this time can be said to be given through a state-centric mechanism.

A new perspective is needed to see democracy in Majanggut I Village without destroying the democratic order that has been running with a locality-based democracy approach. Local based democracy exists to provide a great opportunity for every citizen who has different identities to show their existence in the life of the state.

\section{References}

Barenschot, W and Van Klinken G. (2019). Citizenhip in Indonesia, PerjuanganAtas, Hak, Identitas, dan Partisipasi. Jakarta. Obordan KITLV.

Bikhu P. (2008). Rethinking Multiculturalism KeberagamanBudayadanTeoriPolitik. Yogyakarta. Kanisius.

Diamond, L. (2003). Developing Democracy Toward Consolidation. Yogyakart. IRE

Hadiz, R.V. (2003). "Power and Politics in North Sumatra: The Uncompleted Reformasi" dalam Local Power and Politics in Indonesia. Singapore. Institute of Southeast Asian Studies.

Harison, L. (2007). MetodologiPenelitianPolitik. Jakarta.Kencana.

Kartodirdjo, Sartono (ed). (1990). PestaDemokrasi di Pedesaan. Yogyakarta. P3KP UGM.

Kymlica, W. (2015). KewarganegaraanMultikultural. Jakarta. LP3ES.

Santoso P. (2018). "LokalitasSebagaiKonteksUntukBerdemokrasi"dalamRezimLokal di Indonesia MemaknaiUlangDemokrasi Kita. Jakarta. Obor

Santoso P and Akbar. (2018). "Resetting Agenda Demokratisasi" dalamRezimLokal di Indonesia MemaknaiUlangDemokrasi Kita. Jakarta. Obor.

Savirani. et.al. (2006). Reclaiming The State; Mengatasi Problem Demokrasi di Indonesia PascaSoeharto. Yogyakarta. PolGovdan PCD Press.

Stoke, K. (2018). "PolitikKewargaan: KerangkaAnalisis" dalamPolitikKewargaan di Indonesia (Editor Eric HiariejdanKrisitian Stoke). Jakarta. YayasanObor Indonesia bekerjasamadengan UGM dan Universitas Oslo Norwegia.

Stoke, K. (2018). "Politics of citizenship: Towards an analytical framework".NorskGeografiskTidsskrift - Norwegian Journal of Geography, 71:4, 193207, DOI: 10.1080/00291951.2017.1369454. 